\title{
Bender Gestalt Visual-Motor Test - Sistema de Pontuação Gradual (B-SPG): A Study With Different Samples
}

\author{
Ana Paula Porto Noronha ${ }^{1}$ \\ Fabián Javier Marín Rueda \\ Acácia Aparecida Angeli dos Santos \\ Universidade de São Francisco, Itatiba-SP, Brazil
}

\begin{abstract}
The aim in this study was to analyze differences between children's performances on the Bender - Sistema de Pontuação Gradual (B-SPG) [Gradual Scoring System] in the states of Minas Gerais and Paraíba, and to compare them with the results presented in the test manual. The participants were 511 children, both sexes, aged 6-10 years $(M=8.21, S D=1.33)$, and $50.7 \%$ male. The children were from two states, Minas Gerais $(n=298,58.3 \%)$ and Paraiba $(n=213,41.7 \%)$. The SPG was administered collectively in classrooms. The mean B-SPG scores between the children from Minas Gerais and Paraiba were very similar and not statistically significant. Regarding the comparison between the two states and the normative sample, three results were significant, two of which favored the children from São Paulo and the other the children from Minas Gerais and Paraíba, showing little variation in the results of the B-SPG.
\end{abstract}

Keywords: psychological assessment, psychological testing, Bender test

\section{Teste Gestáltico Visomotor de Bender - Sistema de Pontuação Gradual (B-SPG): Um Estudo com Amostras Distintas}

\begin{abstract}
Resumo: O presente estudo tem como objetivo analisar diferenças entre os desempenhos no Bender - Sistema de Pontuação Gradual (B-SPG) de crianças dos estados de Minas Gerais e Paraíba, bem como comparar com os resultados apresentados pelo manual do teste. Participaram da pesquisa 511 crianças, ambos os sexos, com idades variando de 6 a 10 anos $(M=8,21$, $D P=1,33$ ), sendo $50,7 \%$ do sexo masculino. As crianças eram provenientes de dois estados, quais sejam Minas Gerais $(n=298,58,3 \%)$ e Paraíba $(n=213,41,7 \%)$. O B-SPG foi aplicado coletivamente nas salas de aula. As pontuações médias no B-SPG das crianças de Minas Gerais e da Paraíba foram muito próximas e não significativas estatisticamente. No que diz respeito à comparação entre os dois estados e a amostra normativa, três resultados foram significativos, sendo que dois favoreceram as crianças de São Paulo e o outro, as de Minas Gerais e Paraíba, revelando pouca variação nos resultados do B-SPG.
\end{abstract}

Palavras-chave: avaliação psicológica, testes psicológicos, teste de Bender

\section{Prueba Gestáltica Viso-Motriz de Bender - Sistema de Pontuação Gradual (B-SPG): Un Estudio con Muestras Diferentes}

\begin{abstract}
Resumen: Este estudio tiene como objetivo analizar diferencias entre los desempeños en el Bender - Sistema de Pontuação Gradual (B-SPG) [Sistema de Puntación Gradual] de niños de los estados de Minas Gerais y Paraíba, Brasil, y compararlos con los resultados presentados en el manual de la prueba. Participaron 511 niños, ambos sexos, con edades variando de 6 a 10 años $(M=8,21, D E=1,33)$, siendo el 50,7\% del sexo masculino. Los niños provenían de dos estados: Minas Gerais $(n=298$, $58,3 \%)$ y Paraíba $(n=213,41,7 \%)$. El B-SPG fue aplicado de forma grupal en las clases. Los promedios de puntuaciones en el B-SPG de Minas Gerais e Paraíba fueron próximos y no significativos. Respecto a la comparación entre los dos estados y la muestra normativa, tres resultados fueron significativos, siendo que dos entre ellos favorecieron a los niños de São Paulo y el otro a los niños de Minas Gerais y Paraíba, mostrando poca variación en los resultados del B-SPG.
\end{abstract}

Palabras clave: evaluación psicológica, tests psicológicos, test de Bender

Experts have reflected on the quality of Brazilian psychological tests for almost half a century. In that sense, different investments have been observed in the history of Brazilian psychology with a view to the development, adaptation and translation of instruments and techniques for use in the country (Noronha \& Reppold, 2010; Pasquali \& Alchieri, 2001). Almost a decade age, the American Educational Research

\footnotetext{
Correspondence address:

Ana Paula Porto Noronha. Rua Alexandre Rodrigues Barbosa, 45, Centro. CEP 13251-900. Itatiba-SP, Brazil. E-mail: ana.noronha@usf.edu.br
}

Association [AERA], American Psychological Association [APA] and National Council on Measurement in Education [NCME] (1999) published the revised version of the Standards for Educational and Psychological Tests, launched in the United States in 1950, which was used as a parameter for the use, construction and revision of psychological tools.

Among the orientations available in the Standards, standardization will be highlighted, as it is more directly related with the objectives of this research. Standards refer to the criteria established to determine individual results for the sake of comparison with a standard group. This group, in turn, 
should be chosen based on the characteristics that are relevant to analyze the construct that is focused on. Hence, the standards make it possible to estimate the expected parameters for the population the subject is being compared with, as well as to give meaning to numerical scales (Urbina, 2007). To establish standards, a carefully selected sample group is needed, as direct access to the entire population is extremely difficult and would make research unfeasible. Therefore, the quality of standards is related to the representativeness of the group (Adanéz, 1999; Anastasi \& Urbina, 2000).

Brazil is a continental country and, therefore, studies with diversified samples are to be recommended. In addition, psychological tools need constant updating, justifying the present research, aimed at investigating perceptual-motor maturity with the help of the Bender - Sistema de Pontuação Gradual (B-SPG), involving participants from distinct Brazilian regions. The B-SPG was constructed based on the premises of Bender (1955), particularly on the belief that visual-motor gestalt maturation can be verified through the reproduction of drawings. The instrument uses nine figures the subject needs to copy on a blank paper. The system establishes a gradual score ranging from one to three, according to the type of error, and only assesses the distortion of the shape (Sisto, Noronha, \& Santos, 2005).

As the Bender test dates back to the 1930's (Bender, 1938) and is used in different countries around the world, in Brazil, some of its correction and interpretation systems, particularly the Kopitz system, have been taught in many psychology courses at different universities (Alves, Alchieri, $\&$ Marques, 2002; Pereira \& Carellos, 1995). The free access to the available correction and interpretation systems turned the Bender into one of the most used tools in the country (Noronha et al., 2002). When the Federal Board of Psychology [CFP] (2003) implemented CFP Resolution 02/2003, which set minimal criteria for the use, construction and trading of psychological tests, the Bender stopped being used. In the study by Suehiro, Gaino and Meireles (2008), based on ten journals and covering the period from 2003 to 2008, it was shown that few studies used the instrument, as the authors found only 18 papers.

Particularly regarding research using the B-SPG, some researchers have already published their findings (Sisto, Santos, \& Noronha, 2010). Suehiro and Santos (2005) studied the existing association between perceptual-motor maturity and learning difficulties. Carvalho and Noronha (2009) detected a negative correlation between the Bender scores and the reading comprehension level. The thesis by Luca (2011) was also focused on learning, using the School Performance Test (TDE) to show that, the higher the Bender scores (which scores errors), the worse the school performance.

Research on the possible relations between intelligence and perceptual-motor maturity led to the largest number of publications using the B-SPG. In all of them, highly similar results were obtained, using different intelligence measures, systematically indicating a negative correlation between different intelligence tests and the Bender score, whose main characteristic is that it scores right answers. In that sense, in a single year, the studies by Sisto, Bartholomeu, Rueda, Santos and Noronha (2008) and by Bartholomeu and Sisto (2008) were identified. While the former used Raven's Colored Progressive Matrices, in the latter, the DFH-Sisto Scale was used to measure intelligence.

This association between intelligence and perceptual-motor maturity was also analyzed in samples from different populations. Pacanaro, Santos and Suehiro (2008) and Vendemiatto, Santos and Suehiro (2008) applied the instruments in samples with specific characteristics, the first referring to adolescents in social risk situations and the latter in people suffering from Down's Syndrome. Neri, Santos and Lima (2008) studied deaf children, while Santos and Jorge (2007) applied the B-SPG in a group of dyslexic young people and adults. In the same period, Suehiro, Rueda and Silva (2007) explored performance differences on the Bender-SPG when comparing sheltered and non-sheltered children.

Other researchers investigated the convergence between perceptual-motor maturity and personality traits. In the author's doctoral dissertation, Mattos (2009) used the Personality Traits Scale for Children (ETPC), registering positive correlation coefficients between B-SPG scores and extroversion and negative coefficients with neuroticism. Earlier, Santos and Noronha (2006) had applied the ETPC to children and observed results that were very similar to Mattos' study.

The final three studies found had different objectives from those mentioned so far. Suehiro and Santos (2006) attempted to study variations between school years and B-SPG scores and identified that, the more advanced the school pha$\mathrm{se}$, the lesser the number of errors. Lima, Cunha, Santos and Mognon (2010) observed a negative and significant correlation with the perceptual-motor maturity of children using electronic games. Pinto and Noronha (2010) analyzed developmental changes related to the B-SPG and checked for possible differences in the mean scores when considering the school year and type of school, favoring children from more advanced years and private schools.

Based on the above, one can infer that, although the system studied here is recent (Sisto et al., 2005) and a reasonable amount of publications is available, studies that investigated different samples are still incipient, considering geographic location and the respective cultural characteristics, as the majority involved samples from the state of São Paulo. In this respect, in the 1980's, Kroeff (1988), using the Koppitz scoring system (1975), identified the need to construct Brazilian standards, as that author's findings revealed differences between children from Porto Alege and Koppitz' standard group. That research included 1082 male and female children between 5 and 10 years of age.

In the same sense, with a view to checking for possible performance differences between samples with distinct cultural characteristics, Mazzeschi and Lis (1999) investigated 1065 Italian children between 3 and 11 years of age and used the Koppitz system (1975) for correction. Therefore, the authors determined groups from different Italian regions 
and ethnic origins. As opposed to the results found by Kroeff (1988) for Brazilian and North American children, no performance variations were found when considering ethnic, regional or sociocultural aspects, possibly because the sample only included Italian children.

Viljoen, Levett, Tredoux and Anderson (1994) investigated 882 people between 6 and 18 years of age in South Africa, with a view to setting standards and exploring the influence of variables like age, gender, educational level and geographical area on performance. The application of the Koppitz standards showed to the inappropriate and geographical differences exerted a mild effect on the research sample. In a more recent study, Chan (2000) indicated difficulties to compare the results of the Bender for Chinese children between 4 and 8 years of age, also when assessed using the Koppitz system. The author endorsed the need to study specific criteria for children in that country.

Regarding the perceptual-motor maturity construct, Bender (1955) considered that performance on the instrument was hardly subject to cultural influences, as the figures reproduced gestalt patterns. Some of the studies retrieved here, however, indicate some performance differences on the Bender, in the Koppitz system as well as in the Bender Sistema de Pontuação Gradual (B-SPG).

In view of the relevant assertion that the universality of systems should always be challenged, this study was intended to compare the performance on the Bender Gestalt Visual-Motor Test - Sistema de Pontuação Gradual (Sisto et al., 2005) among children from different Brazilian regions. First, differences were sought between the states of Minas Gerais and Paraíba. Then, the results of children from these states were compared with the results presented in the test manual, which sets standardized scores from children between 6 and 10 years of age in the state of São Paulo.

\section{Method}

\section{Participants}

The research participants were 511 children, male and female, between 6 and 10 years of age $(M=8.21, S D=1.33)$, with $50.7 \%$ of boys. The children came from two states, Minas Gerais and Paraíba.

The distribution of the sample between the states was reasonably homogeneous, as $298(58.3 \%)$ children came from Minas Gerais and 213 (41.7\%) from Paraíba. As regards gender and age, the distribution between both states was also similar, although more children from Minas Gerais participated of all ages and for each gender, except for eight-year-old girls, with more children from Paraíba.

\section{Instrument}

Bender Gestalt Visual-Motor Test - Sistema de Pontuação Gradual (B-SPG) (Sisto et al., 2005): consists of nine figures (A, 1, 2, 3, 4, 5, 6, 7 and 8; in figure 7, the two hexagons are analyzed), individually displayed for the subject to copy them on a blank sheet of paper. No rubber or any other mechanical help should be used in the reproduction. The projection of the figures comes with the instruction for the children to copy the nine models on a single sheet of paper, as well as they can. The test can be applied individually or in group.

In the B-SPG, each figure receives a gradual score ranging from zero to three, according to the severity of the error. This permits a total score of 21 points, as scores for figures A, 1, 2, 3, 4, 5, 7a, $7 \mathrm{~b}$ and 8 can range between 0 and 2, and for figure 6 between 0 and 3 . The errors correspond to the presence of deviations in each of the figures included in the Bender gestalt test. If there are no deviations regarding the distortion of the form, the score equals zero.

Validations and precision studies have been elaborated using the B-SPG. Among the validations, a moderate negative correlation $(r=-0.58 ; p<.001)$ stands out between age $(6$ and 10 years) and B-SPG score, confirming the theoretical premises. This result indicates that, as age advances, the B-SPG score drops, that is, distortions in the reproduction of the figures decrease progressively, according to the increasing age.

Concerning the differences of means among the age groups (6 to 10 years) and possible distinctions, ANOVA and Tukey's test were used. In ANOVA, the variables age and gender were considered $(4 \times 2)$. The result showed age as the main source of variance and the only variable with statistically significant differences. As for gender, the results were not significant, that is, the variable did not serve as a sufficient source of variance to produce more than random differences. What precision is concerned, the analyses developed using Cronbach's alpha, Spearman-Brown's split-half method and the Rasch model indicated satisfactory coefficients. Inter-rater precision was also analyzed, revealing an agreement rate of more than $80 \%$ in all cases.

Standards were set and the above psychometric properties were studied based on a sample of 1052 children from eight schools in São Paulo state. Ages ranged between 6 and 10 years, with a mean age of 8.35 years and a standard deviation of 1.29 . Concerning gender, $51.1 \%$ were boys and education varied between preschool and the $4^{\text {th }}$ year of basic education.

\section{Procedure}

Data collection. After the Ethics Committee had approved the project and the parents or legal caregivers had received the Informed Consent Term to authorize the children's participations, two psychologists experienced in the data collection and application of the B-SPG applied the test in group, at a previously scheduled time, one in each state. For the application, the orientations in the test manual were complied with, which informs that the "projector should be placed at about two meters from the screen and there should be up to 30 children in the room at most" (Sisto et al., 2005, p. 66). Initially, literate children completed their identification data, while children unable to provide 
this information received help. Then, the participants were asked to copy, as well as they could, the figures that were drawn on a transparency, which were presented to them with the help of an overhead projector. The approximate duration of each application was 15 minutes. Two judges corrected the protocols, who were psychologists with great experience in the correction and interpretation of the Bender Test, strictly complying with the orientations and instructions for correction in the test manual.

Data analysis. To comply with the proposed objectives, descriptive and inferential statistics were used. More specifically, Student's t-test was used to compare ages, genders and States with regard to the B-SPG. Also, MONOVA permitted comparing the B-SPG in function of the State and the children's age.

\section{Ethical Considerations}

The project was submitted to the Research Ethics Committee at Universidade São Francisco, in compliance with National Health Council Resolution 196/96, and approved under protocol number CAAE: 0059.0.142.000-07. After its approval, data collection was started.

\section{Results}

To achieve the proposed objectives, first, the children's performances were compared between the states of Minas Gerais and Paraíba, separately considering each age. The results have been displayed in Table 1.

Table 1

Mean Scores, Standard Deviation, $t$ and $p$ Values on B-SPG for Each Age and in the General Sample in Function of the State

\begin{tabular}{lcccccc}
\hline Age & State & $N$ & $M$ & $D P$ & $t$ & $p$ \\
\hline 6 years & MG & 35 & 13.17 & 3.59 & -0.42 & .679 \\
& PB & 27 & 13.59 & 4.38 & & \\
7 years & MG & 67 & 11.91 & 3.90 & -0.12 & .908 \\
& PB & 44 & 12.00 & 4.13 & & \\
8 years & MG & 54 & 9.70 & 3.30 & 1.21 & .228 \\
& PB & 55 & 8.78 & 4.54 & & \\
9 years & MG & 74 & 7.66 & 3.35 & 0.43 & .669 \\
& PB & 43 & 7.37 & 3.83 & & \\
10 years & MG & 68 & 6.43 & 3.24 & 1.93 & .056 \\
& PB & 44 & 5.27 & 2.85 & & \\
6 to 10 & MG & 298 & 9.35 & 4.22 & 0.76 & .449 \\
years & PB & 213 & 9.05 & 4.86 & & \\
\hline
\end{tabular}

In Table 1, it is shown that the children's mean scores on the B-SPG were very similar between Minas Gerais and Paraíba. In addition, the detected differences were not statistically significant, except at the age of 10 years, with a marginally significant difference $(p=.056)$.
As the B-SPG manual informs that, at the ages of 7 and 10 years, the children's score should be interpreted separately in function of their gender, the researchers decided to compare both genders in these two age groups. The analysis results are displayed in Table 2.

Table 2

Mean Scores, Standard Deviation, $t$ and $p$ Values on B-SPG for the Ages 7 and 10 Years in Male and Female Children

\begin{tabular}{lccccccc}
\hline Age & Gender & State & $N$ & $M$ & $S D$ & $t$ & $p$ \\
\hline 7 years & Male & MG & 39 & 12.74 & 3.81 & 1.27 & .209 \\
& & PB & 23 & 11.43 & 4.10 & & \\
7 years & Female & MG & 28 & 10.75 & 3.79 & -1.64 & .109 \\
& & PB & 21 & 12.62 & 4.18 & & \\
10 years & Male & MG & 40 & 6.28 & 3.34 & 1.72 & .090 \\
& & PB & 29 & 4.93 & 3.00 & & \\
10 years & \multirow{2}{*}{ Female } & MG & 28 & 6.64 & 3.13 & 0.76 & .453 \\
& & PB & 15 & 5.93 & 2.49 & & \\
\hline
\end{tabular}

The analysis in function of the children's gender at the ages of 7 and 10 years also showed that occasional score differences were random $(p>.05)$, showing no significant differences between the mean scores when comparing girls and boys. Then, MANOVA was applied to check for significant differences in B-SPG performance in function of the interaction between the state and the children's age. The results are shown in Table 3.

Table 3

Multivariate Analysis of Performance on B-SPG in Function of the Children's State and Age

\begin{tabular}{lcc}
\hline & $F$ & $p$ \\
\cline { 2 - 3 } State & 1.18 & .279 \\
Age & 61.83 & .000 \\
State x Age & 0.72 & .579 \\
\hline
\end{tabular}

In Table 3, the B-SPG scores show a statistically significant difference when considering the age variable. As observed, the children's state of origin was a variable that resulted neither in any significant differences in the test scores, nor in any association with the state of the federation. To check the age scores that could explain the observed difference, Tukey's test was applied, and the results are displayed in Table 4.

Table 4

Age Groups Constituted Using Tukey's Test for B-SPG

\begin{tabular}{lccccc}
\hline \multirow{2}{*}{ Age } & \multirow{2}{*}{$\mathrm{N}$} & \multicolumn{4}{c}{ Subgroups for alpha $=0.05$} \\
\cline { 3 - 6 } & 112 & 5.97 & 2 & 3 & 4 \\
\hline 10 & 117 & & 7.56 & & \\
9 & 109 & & & 9.24 & \\
8 & 111 & & & & 11.95 \\
7 & 62 & & & & 13.35 \\
6 & 511 & 1.000 & 1.000 & 1.000 & .063 \\
$p$ & & & & & \\
\hline
\end{tabular}


Based on Tukey's test, four age groups were identified for the B-SPG, without any mutual distinctions between 6 and 7-year-old children. When comparing this result with the B-SPG manual, the study underlying the latter distinguished among the five ages under investigation, with higher ages corresponding to lower scores. More particularly, it could be observed that, except for the 6 and 7 -year-olds, in the other ages, the number of formal distortions dropped significantly. Hence, as the children's age advanced, the score also decreased.

Finally, this study compared the present sample data with the results in the test manual. Therefore, the data from the children in Minas Gerais and Paraíba were considered on the whole, as none of the comparisons made had revealed any mutual differences. In Table 5, the comparative data between both states and the scores for São Paulo State as shown in the test manual are displayed (Sisto et al., 2005).

Based on Table 5, statistically significant differences are observed in three out of seven comparisons made. In that sense, six-year-old children in Minas Gerais and Paraíba showed a lower mean score than children of the same age in São Paulo State, which means that children from Minas Gerais and Paraíba performed better. When comparing 7-year-old

Table 5

Comparison Between the B-SPG Score of the Present Sample and the Test Manual Sample for Each Age and in the General Sample

\begin{tabular}{lcccccc}
\hline Age/Gender & State & $N$ & $M$ & $S D$ & $t$ & $p$ \\
\hline 6 years & MG and PB & 62 & 13.35 & 3.93 & -2.02 & .048 \\
general & SP & 111 & 14.36 & 3.55 & & \\
7 years male & MG and PB & 62 & 12.26 & 3.94 & 4.60 & $<.001$ \\
& SP & 83 & 9.96 & 3.77 & & \\
7 years & MG and PB & 49 & 11.55 & 4.03 & 0.52 & .603 \\
female & SP & 77 & 11.25 & 3.70 & & \\
8 years & MG and PB & 109 & 9.24 & 3.98 & 0.34 & .737 \\
general & SP & 303 & 9.11 & 3.50 & & \\
9 years & MG and PB & 117 & 7.56 & 3.52 & 1.37 & .174 \\
general & SP & 210 & 7.11 & 3.77 & & \\
10 years & MG and PB & 69 & 5.71 & 3.25 & -0.20 & .839 \\
male & SP & 135 & 5.79 & 3.34 & & \\
10 years & MG and PB & 43 & 6.40 & 2.91 & 3.16 & .003 \\
female & SP & 133 & 4.99 & 2.83 & & \\
\hline
\end{tabular}

boys and 10-year-old girls, statistically significant differences were also found, with a better performance among children from the normative sample (São Paulo state).

\section{Discussion}

Specific normative studies are needed for evaluation samples (AERA, APA, \& NCME, 1999; Urbina, 2007). As regards Brazil, in view of the country's physical dimensions, with distinct regional and cultural characteristics and the small number of standard-setting publications about the
Bender test (Kroeff, 1988; Suehiro et al., 2008), this kind of research is fundamental. About a decade ago, Adanéz (1999) asserted that the representativeness of the sample group is related to the quality of the standards.

The intent in this study was to compare the performance of children in Minas Gerais and Paraíba and with the standard sample in the Bender manual - Sistema de Pontuação Gradual. The results revealed that there were no statistically significant differences between the samples from different states when the participants were grouped per age. Similarly, when the results were compared per gender, no significant difference was found among the children. To proceed with the analyses, the children were organized in five age groups and Minas Gerais and Paraíba were compared with the normative sample, including children from the state of São Paulo. Three out of seven results revealed significant differences (6 years, 7 years - male and 10 years - female). It should be reminded that the ages of 7 and 10 years are displayed in separate tables according to gender in the B-SPG manual, in view of statistically significant differences. Therefore, in this analysis, the results were separated per gender.

This explains why the performance levels in Minas Gerais and Paraíba show more mutual similarities than between each of these and São Paulo, although it should be kept in mind that the differences observed with regard to the normative sample occurred in less than half of the comparisons made. Bender (1955) had asserted test performance as being hardly susceptible to culture, as it involved the reproduction of geometrical drawings. That assertion partially reproduces the present study findings. In this respect, in the research that used the Koppitz system, distinct performances were found for children from different countries (Chan, 2000), as well as non-significant results for children from different regions in the same countries (Mazzeschi \& Lis, 1999) and partially similar results for the same country (Viljoen et al., 1994). In Brazilian studies, in a comparison between Brazilian and North American children's performances, Kroeff (1988) found significant variations in the results.

To a certain extent, the lack of agreement among the findings and the small number of Brazilian studies that intended to understand cultural differences (Suehiro et al., 2008) underline the need to continue developing research with these goals. Finally, research with children from other states is needed, as well as with samples of children showing atypical development, with a view to deriving specific standards.

\section{Final Considerations}

In a continental country like Brazil, validity evidence obtained to interpret a given test, based on study made in a sole region of the country, have caused polemics regarding the application of single standards that ignore possible regional differences. Departing from the premise that test validity should always be challenged, systematic studies are needed, using different samples than those used to standardize the instrument, always permitting further knowledge on its use 
and analyzing the appropriateness of its interpretation in different contexts and for distinct purposes.

As a research limitation, the sample composition should be taken into account. To accomplish the study, sociodemographic variables were not controlled for, and a sole city was considered each time. Therefore, these aspects should be considered in further research.

The results obtained with children from Minas Gerais and Paraíba, when mutually compared and with the children from São Paulo, where the data underlying the standards were taken from, reinforce existing evidence for the validity of the interpretations attributed to the visual-motor maturity, based on the scores obtained through the Bender - Sistema de Pontuação Gradual (B-SPG). It is important to highlight that visual-motor maturity, the construct measured by means of that instrument, expects developmental differences among children in this age range, accompanied by a gradual reduction in the number of errors they commit.

Hence, based on the study findings, it can be affirmed that the standards initially established using the sample from São Paulo can be used with children from other geographic locations, as one of the main evidences for the validity of the Bender-SPG, related to the sensitivity of the criterion variable age, was maintained for the new samples, confirming the idea that the system is suitable for professional use in other Brazilian regions.

\section{References}

Adanéz, G. P. (1999). Procedimientos de construcción y análisis de tests psicométricos. In S. M. Wechsler \& R. S. L. Guzzo (Orgs.), Avaliação psicológica: Perspectiva internacional (pp. 57-100). São Paulo, SP: Casa do Psicólogo.

American Educational Research Association, American Psychological Association, \& National Council on Measurement in Education. (1999). Standards for educational and psychological testing. Washington, DC: American Psychological Association.

Anastasi, A., \& Urbina, S. (2000). Testagem psicológica (M. A. V. Veronese, Trad.). Porto Alegre, RS: Artmed.

Alves, I. C. B., Alchieri, J. C., \& Marques, K. C. (2002). As técnicas de exame psicológico ensinadas nos cursos de graduação de acordo com os professores. PsicoUSF, 7(1), 77-88.

Bartholomeu, D., \& Sisto, F. F. (2008). Maturidade viso-motora e inteligência: Um estudo correlacional. Psicologia: Ciência e Profissão, 28(2), 362-373. doi:10.1590/S1414-98932008000200011

Bender, L. (1938). A visual motor Gestalt test and its clinical use. New York, NY: The American Orthopsychiatric Association.

Bender, L. (1955). Test guestáltico visomotor: Usos y aplicaciones clínicas (D. Carnelli, Trad.). Buenos Aires, Argentina: Paidós.
Carvalho, L., \& Noronha, A. P. P. (2009). Maturidade perceptomotora e compreensão em leitura: Um estudo correlacional. In A. A. A. Santos, E. Boruchovitch, \& K. L. Oliveira (Orgs.), Cloze: Um instrumento de diagnóstico e intervenção (pp. 227-247). São Paulo, SP: Casa do Psicólogo.

Chan, P. W. (2000). Relationship of visual motor development and academic performance of young children in Hong Kong assessed on the Bender-Gestalt test. Perceptual and Motor Skills, 90(1), 209-214. doi:10.2466/PMS.90.1.209-214

Conselho Federal de Psicologia. (2003). Resolução $N^{o}$ 002/2003. (2003, 24 de março). Define e regulamenta o uso, a elaboração e a comercialização de testes psicológicos e revoga a Resolução CFP ${ }^{\circ}$ 025/2001. Retrieved from http://www.pol.org.br/ ou http://www2.pol.org.br/satepsi/CD_testes/pdf/ Resolu\%E7\%E3o\%20CFP\%20n\%BA\%20002-03\%20 -\%20sem\%20anexo.pdf

Koppitz, E. M. (1975). The Bender-Gestalt Test for young children: Vol. 2. Research and application, 1963-1973. New York, NY: Grune \& Stratton.

Kroeff, P. (1988). Normas brasileiras para o Teste de Bender. Psicologia: Reflexão e Crítica, 3(1/2), 12-19.

Lima, T. H., Cunha, N. B., Santos, A. A. A., \& Mognon, J. F. (2010). Desenvolvimento visomotor e uso de jogos eletrônicos em crianças do Ensino Fundamental. Estudos Interdisciplinares em Psicologia, 1(2), 202-215.

Luca, L. (2011). Teste Gestaltico Visomotor de Bender (B-SPG): Estudo de validade com uma amostra paraibana (Unpublished Masters Dissertation). Universidade São Francisco, Itatiba, SP.

Mattos, R. M. C. B. (2009). Bender Sistema Pontuação Gradual (B-SPG): Estudo correlacional entre percepção visomotora, cognição e personalidade (Unpublished Ph.D. Thesis). Universidade São Francisco, Itatiba, SP.

Mazzeschi, C., \& Lis, A. (1999). The Bender-Gestalt test: Koppitz's developmental scoring system administered to two samples of Italian preschool and primary school children. Perceptual and Motor Skills, 88(3, Pt.2), 1235-1244. doi:10.2466/PMS.88.3.1235-1244

Neri, M. L., Santos, A. A. A., \& Lima, T. H. (2008). Habilidade viso-motora de crianças surdas avaliadas pelo Bender-SPG. In A. P. Noronha, C. Machado, L. Almeida, M. Gonçalves, S. Martins, \& V. Ramalho (Coords.), Avaliação psicológica: Formas e contextos (Vol. 13, pp. P3.13). Braga, Portugal: Psiquilíbrios.

Noronha, A. P. P., Oliveira, A. F., Cobêro, C., Paula, L. M., Cantalice, L. M., Guerra, P. B. C., Martins, R. M. M., \& Felizatti, R. (2002). Instrumentos psicológicos mais conhecidos por estudantes do Sul de Minas Gerais. Avaliação Psicológica, 1(2), p. 151-158. 
Noronha, A. P. P., \& Reppold, C. T. (2010). Considerações sobre a avaliação psicológica no Brasil. Psicologia: Ciência e Profissão, 30 ( $\mathrm{N}^{\circ} \quad$ Esp.), 192-201. doi:10.1590/S1414-98932010000500009

Pacanaro, S. V., Santos, A. A. A., \& Suehiro, A. C. B. (2008). Avaliação das habilidades cognitiva e visomotora em pessoas com Síndrome de Down. Revista Brasileira de Educação Especial, 14(2), 311-326. doi:0.1590/S1413-65382008000200011

Pasquali, L., \& Alchieri, J. C. (2001). Os Testes Psicológicos no Brasil. In L. Pasquali (Org.), Técnicas de Exame Psicológico - TEP: Manual: Vol 1. Fundamentos das técnicas psicológicas (pp. 195-221). São Paulo: Casa do Psicólogo.

Pereira, A. P. C., \& Carellos, S. D. M. (1995). Examinando o ensino das Técnicas de Exame Psicológica. Cadernos de Psicologia, 3(4), 33-36.

Pinto, L. P., \& Noronha, A. P. P. (2010). Maturidade percepto-motora e sua relação com idade e variáveis contextuais: Um estudo com o Bender (B-SPG). Encontro: Revista de Psicologia, 13(19), 145-155.

Santos, A. A. A., \& Jorge, L. M. (2007). Teste de Bender com disléxicos: Comparação de dois sistemas de pontuação. Psico-USF, 12(1), 13-21. doi: $10.1590 / \mathrm{S} 1413-82712007000100003$

Santos, R. S., \& Noronha, A. P. P. (2006). Estudo correlacional entre a maturidade percepto-motora e traços de personalidade. PSIC - Revista de Psicologia da Vetor Editora, 7(2), 39-45.

Sisto, F. F., Bartholomeu, D., Rueda, F. J. M., Santos, A. A. A., \& Noronha, A. P. P. (2008). Relações entre o Teste de Bender e matrizes progressivas coloridas de Raven na avaliação da inteligência. Interação em Psicologia, 12(1), 11-19.

Sisto, F. F., Noronha, A. P. P., \& Santos, A. A. A. (2005). Bender-Sistema de Pontuação Gradual (Bender-SPG). São Paulo: Vetor.

Sisto, F. F., Santos, A. A. A., \& Noronha, A. P. P. (2010). Differential functioning of Bender Visual-Motor Gestalt Test items. Perceptual and Motor Skills, 110(1), 313-322. doi:10.2466/PMS.110.1.313-322

Suehiro, A. C. B., Gaino, S. B., \& Meireles, E. (2008). Produção científica sobre o Teste Gestáltico VisoMotor de Bender entre 1999 e 2008. PSIC - Revista de Psicologia da Vetor Editora, 9(2), 173-181.

Suehiro, A. C. B., Rueda, F. J. M., \& Silva, M. A. (2007). Desenvolvimento percepto-motor em crianças abrigadas e não abrigadas. Paidéia, 17(38), 431-442. doi:10.1590/S0103-863X2007000300012

Suehiro, A. C. B., \& Santos, A. A. A. (2005). O Bender e as dificuldades de aprendizagem: Estudo de validade. Avaliação Psicológica, 4(1), 23-31.

Suehiro, A. C. B., \& Santos, A. A. A. (2006). Evidência de validade de critério do Bender-Sistema de Pontuação. Interação em Psicologia, 10(2), 217-224.
Urbina, S. (2007). Fundamentos da testagem psicológica (C. Dornelles, Trad.). Porto Alegre, RS: Artmed.

Viljoen, G., Levett, A., Tredoux, C., \& Anderson, S. (1994). Using the Bender Gestalt in South Africa: Some normative data for Zulu-speaking children. South African Journal of Psychology, 24(3), 145-151.

Vendemiatto, B. C., Santos, A. A. A., \& Suehiro, A. C. B. (2008). Inteligência e maturidade viso-motora: Estudo com adolescentes em situação de risco. Avaliação Psicológica, 7(3), 439-447.

Ana Paula Porto Noronha is a Professor in the Stricto Sensu Graduate Program in Psychology at Universidade São Francisco.

Fabián Javier Marín Rueda is a Professor in the Stricto Sensu Graduate Program in Psychology at Universidade São Francisco.

Acácia Aparecida Angeli dos Santos is a Professor in the Stricto Sensu Graduate Program in Psychology at Universidade São Francisco.

Received: May $3^{\text {rd }} 2012$

$1^{\text {st }}$ Revision: Oct. $16^{\text {th }} 2012$

Approved: Nov. 28 2012

How to cite this article:

Noronha, A. P., Rueda, F. J. M., \& Santos, A. A. A. (2013). Bender Gestalt Visual-Motor Test - Sistema de Pontuação Gradual (B-SPG): A study with different samples. Paidéia (Ribeirão Preto), 23(55), 179-185. doi:10.1590/1982-43272355201305 


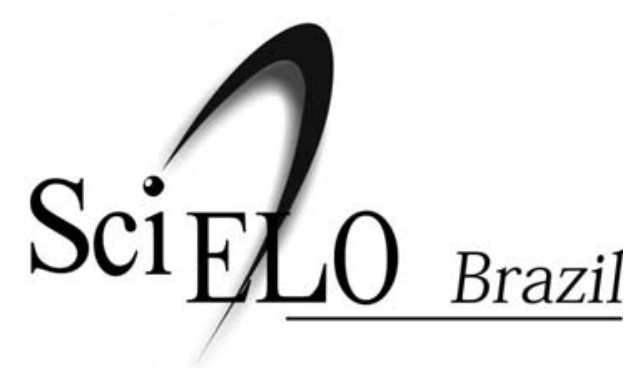

The SciELO interface provides easy access to the tables of content and to the full-text articles.

The SciELO interface also provides the retrieval of articles by the author's name, the words from title, abstract and descriptors, in addition to providing bibliometric indicators and consultation indicators.

The articles are enriched with connections to the LILACS, MEDLINE and PubMed databases.

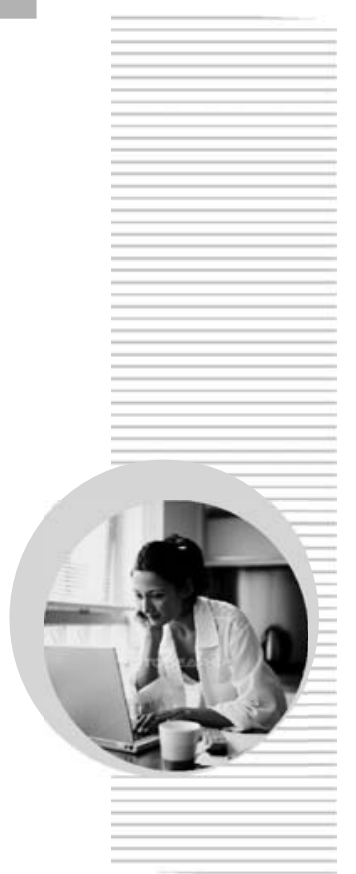

Paidéia (Ribeirão Preto) is a part of SciELO Brazil:

\section{www.scielo.br/paideia}

The SciELO interface provides access to a network of SciELO websites, gathering the major scientific journals of Latin America, Caribbean, Spain, Portugal and South Africa:

\section{www.scielo.org}

The electronic library is a project developed by the São Paulo Research Fundation (FAPESP), in partnership with the Latin American and Caribbean Center on Health Sciences Information (BIREME) and the National Council for Scientific and Technological Development (CNPq). 